\title{
MicroRNA-21 as a biomarker for ovarian cancer detection
}

\author{
Aprilia Indra Kartika ${ }^{1,3, *}$, Siti Nur Chasanah ${ }^{2}$, Akbar Satria Fitriawan ${ }^{2}$, Dewi Sahfitri Tanjung ${ }^{3}$, Addin Trirahmanto ${ }^{4}$, Heru \\ Pradjatmo $^{4}$, Teguh Aryandono ${ }^{5}$, and Sofia Mubarika Haryana ${ }^{6}$ \\ ${ }^{1}$ Faculty of Nursing and Health Sciences, Universitas Muhammadiyah Semarang, Jalan Kedung Mundu Raya No.18, Kedungmundu, \\ Tembalang, Semarang 50273, Indonesia \\ ${ }^{2}$ Biomedical Sciences Graduate Program, Faculty of Medicine, Universitas Gadjah Mada, Jalan Farmako, Sekip Utara, Yogyakarta 55281, \\ Indonesia \\ ${ }^{3}$ Biotechnology Graduate Program, Graduate School of Universitas Gadjah Mada, Jalan Teknika Utara, Barek, Yogyakarta 55281, Indonesia \\ ${ }^{4}$ Department of Obstetrics and Gynecology, Faculty of Medicine, Universitas Gadjah Mada, Jalan Farmako, Sekip Utara, Yogyakarta 55281, \\ Indonesia \\ ${ }^{5}$ Department of Surgery, Faculty of Medicine, Universitas Gadjah Mada, Jalan Farmako, Sekip Utara, Yogyakarta 55281, Indonesia \\ ${ }^{6}$ Department of Histology and Cellular Biology, Faculty of Medicine, Universitas Gadjah Mada, Jalan Farmako, Sekip Utara, \\ Yogyakarta 55281, Indonesia \\ *Corresponding author: apriliaindrak@gmail.com
}

SUBMITTED 22 September 2017 REVISED 10 March 2018 ACCEPTED 25 March 2018

\begin{abstract}
Ovarian cancer is a lethal disease. One of the problems faced by patients with ovarian cancer is the lack of symptoms in its early stages, which results in it only being detected when it is at an advanced stage. Therefore, there is an urgent need for biomarkers that can predict ovarian cancer precisely. The purpose of this study was to determine the expression of microRNA-21 as a predictive biomarker candidate in both early- and advanced-stage ovarian cancer. This was a cross-sectional study using the blood plasma of 21 healthy control subjects and 37 blood plasma samples from patients with ovarian cancer. Blood plasmas were collected, from which the RNA was isolated. Based on the RNA, the cDNA was synthesized and run through qPCR, the results of which were analyzed using the Livak method. The results showed an upregulation of microRNA-21 in the advanced stage by 2.14 fold compared with the early stage, and 6.13 fold compared with the healthy controls $(p<0.05)$. The upregulation of microRNA-21 in early-stage ovarian cancer was 2.86 fold compared with the healthy control subjects $(p<0.05)$. In addition, there was an increase in the expression of microRNA-21 in ovarian cancer by 4.14 fold compared with the healthy controls $(p<0.05)$. Based on these results, it can be concluded that the expression of microRNA 21 upregulated with the severity of the disease.
\end{abstract}

KEYWORDS microRNA-21; minimally invasive; ovarian cancer; predictive biomarker

\section{Introduction}

Ovarian cancer is one of the leading causes of death with most first detections occurring in its late stages (Cannistra 2004). Only $20 \%$ of ovarian cancer patients are diagnosed when the cancer has not yet spread into the ovaries. Conversely, in $80 \%$ of cases, the cancer has metastasized, metastasis that often occurs in the peritoneum (Bast et al. 2009; Cho and Shih 2009). Poor prognosis is associated with multiple factors in ovarian cancer: weak invasive minimum detection, early detection tests, the development of invisible symptoms, and tumor chemoresistance $(\mathrm{Qu}$ et al. 2011). The International Agency for Research on Cancer (IARC) in GLOBOCAN 2012 stated that the total cases of ovarian cancer in Indonesia amounted to 10,238 cases, with the age of most patients being around 60-69 years, and 7,075 of the patients dying. Ovarian cancer was ranked the third incidence in Indonesia, along with the fifth leading cause of cancer-associated mortality in Indonesia. This proves that the incidence of ovarian cancer is associated with a delay in the early detection process, and ovarian cancer causes a decrease in the life expectancy of the community. New biomarkers with high sensitivity and specificity are needed for the diagnosis and therapeutic targets for ovarian cancer. One of these biomarkers that can be used as a candidate for early detection of ovarian cancer is miRNA (Taylor and Gercel-Taylor 2008; Resnick et al. 2009).

MicroRNAs are noncoding RNA molecules that have a nucleotide length of 21-25, and bind to 3 'UTR in mRNA where microRNAs inhibit protein translation or trigger mRNA degradation (Mezzanzanica et al. 2010). microRNAs can function as both oncomers and tumor suppressors. microRNAs also play an important role in cel- 
lular differentiation, cell growth, stress response, and cell death, via modulation of the target mRNA transcription expression (Koutsaki et al. 2014). Specific types of microRNAs target specific mRNAs, microRNAs are stable and are excreted out of cells by vesicles and exosomes and circulate into the bloodstream (Yang et al. 2008; Chao et al. 2014). There are different patterns of miRNA expression in both the serum and plasma of cancer patients compared with healthy controls, which means miRNA can be used as a biomarker candidate to diagnose malignancy (Zhou et al. 2012; Chen et al. 2013).

Several studies related to miR-21 expression in ovarian cancer, miR-21 were exposed to serum from Epithelial Ovarian Cancer (EOC) patients compared with healthy controls (Resnick et al. 2009), overexpression of miR-21 with exosome isolation in plasma of ovarian cancer patients compared to controls, i.e. Benign Ovarian Adenoma (Taylor and Gercel-Taylor 2008), upregulation of miR-21 in the serum of EOC tumor-type ovarian cancer patients was compared to healthy controls (Suryawanshi et al. 2013). The studies that have been conducted in association with the expression of miR-21 in ovarian cancer proved to be a change in expression to overexpression compared with healthy controls. However, the expression of miR-21 in plasma of ovarian cancer patients with the population of Indonesia especially Yogyakarta has not been previously identified. This study aimed to measure changes in miR-21 expression in the plasma of ovarian cancer patients compared with healthy controls using a minimally invasive method.

\section{Materials and methods}

\subsection{Patient samples}

A total of 19 early-stage ovarian cancer patients, 18 advanced-stage patients, and 21 healthy control patients being treated in Sardjito General Hospital, Yogyakarta, Indonesia, were included in the study during the period of September 2015 to May 2016. The subjects' ages ranged from 21 to 70 years old. Stage breakdown was $\mathrm{n}=17$ for stage I, $\mathrm{n}=2$ for stage II, $\mathrm{n}=14$ for stage III, and $n=4$ for stage IV. Informed consent was obtained from each patient prior to sampling. Blood samples up to $5 \mathrm{~mL}$ in volume were drawn from a peripheral venous puncture prior to surgery. The blood was collected using an EDTA tube measuring $5 \mathrm{~mL}$. Immediately after sample collection, the blood samples were centrifuged at $1,500 \mathrm{rpm}$ for $10 \mathrm{~min}$ at $4^{\circ} \mathrm{C}$. Plasma was transferred into $1.5 \mathrm{~mL}$ RNase-free tubes using a tip filter, and then the plasma was stored at $-80^{\circ} \mathrm{C}$ until further use. Ethical approval was obtained from the Medical and Health Research Ethics Committee (MHREC), Faculty of Medicine, Universitas Gadjah Mada-Dr. Sardjito General Hospital (Ref: KE/FK/085/EC/2015) and all plasma samples were acquired with the informed consent of the respective individuals.

\subsection{MicroRNA isolation and real-time quantitative PCR}

The plasma sample of $-80^{\circ} \mathrm{C}$ was melted and then centrifuged at $3000 \mathrm{~g}$, for $5 \mathrm{~min}$ at $4^{\circ} \mathrm{C}$ and taken as much as $200 \mu \mathrm{L}$. Total RNA was extracted using miRCURY RNA Isolation Kit-Biofluid kit according to manufacturer's instruction (Exiqon, Denmark). RNA is stored in a refrigerator $-80^{\circ} \mathrm{C}$ for reuse.

Immediately done DNA synthesis of RNA was obtained. Making cDNA is done using a Universal cDNA Synthesis kit according to manufacturer's instruction (Exiqon, Denmark). The preparation and distribution of the master mix was done by mixing the $4 \mu \mathrm{L} 5 \mathrm{x}$ reaction buffer, $9 \mu \mathrm{L}$ Nuclease free water, $2 \mu \mathrm{L}$ Enzyme mix, and 1 $\mu \mathrm{L}$ Spike in (sp6), up to a total volume of $16 \mu \mathrm{L}$ reagents and sprayed with $4 \mu \mathrm{L}$ RNA samples up to total volume $20 \mu \mathrm{L}$ per reaction. The reaction mixture was incubated at $42^{\circ} \mathrm{C}$ for $60 \mathrm{~min}$, inactivated reverse transcriptase at $95^{\circ} \mathrm{C}$ for $5 \mathrm{~min}$, and cooling down at $4^{\circ} \mathrm{C}$. The cDNA synthesis results were stored in a refrigerator at $-20^{\circ} \mathrm{C}$.

Furthermore, cDNA was diluted with RNase-free water at a ratio of 1:80, ie $1 \mu \mathrm{L}$ cDNA with $80 \mu \mathrm{L}$ RNase-free water. Real Time Quantitative PCR using ExiLent SYBR Green master mix kit according to manufacturer's instruction (Exiqon, Denmark). primary set (forward and reverse) microRNA, cDNA that has been made before. The RNA is then prepared mixed master mix for the target miR16 as the reference gene, miR-21, and $1 \mathrm{H}_{2} \mathrm{O}$. As many as 5 $\mu \mathrm{l}$ SYBR Green master mix, and $1 \mu \mathrm{l}$ mixed primary PCR mix (for each differentiated mixture). $4 \mu \mathrm{L}$ cDNA coupled with $6 \mu \mathrm{L}$ master mix. The reaction mixture was incubated at $95^{\circ} \mathrm{C}$ for $10 \mathrm{~min}$, followed by 40 cycles of $95^{\circ} \mathrm{C}$ for 10 $\mathrm{s}, 60^{\circ} \mathrm{C}$ for $1 \mathrm{~min}$ ramp-rate $1.6^{\circ} \mathrm{C} / \mathrm{s}$ optical read and analyzed melting curve. The result of qRT-PCR duplicate, and miR-16 was used as the internal control. The relative miR-21 expression was calculated using the equation $2-\Delta \Delta C t$, the difference between the original copy number of miR-21 in the ovarian cancer group and that in the healthy control, $-\Delta \Delta C t=(C t$ miR-21 $-C t$ miR-16) of the ovarian cancer group, $-(C t$ miR-21 $-C t$ miR-16) of the healthy control.

\subsection{Statistical analyses}

All statistical analyses were carried out using SPSS. $p$ values $<0.05$ were considered statistically significant. Data were expressed as the mean \pm SD. Expression of miR-21 in both early-stage and advanced-stage ovarian cancer was analyzed using ANOVA and to compare two variables using the Mann-Whitney test.

\section{Results}

\section{1. miR-21 undergoes upregulation in plasma sam- ples of ovarian cancer}

The non-parametric Mann-Whitney test was employed to compare miR-21 expression in patients with ovarian can- 
TABLE 1 Expression of miR-21 in plasma samples of ovarian cancer and healthy control.

\begin{tabular}{lllll}
\hline Plasma samples & miRNA targeted & Mean $(\Delta \mathrm{Cq}) \pm \mathrm{SD}$ & $\Delta \Delta \mathrm{Cq}$ & Fold change $\left(2^{-\Delta \Delta \mathrm{Cq})}\right.$ \\
\hline Ovarian cancer & $\begin{array}{l}\text { miR-21 as target } \\
\text { miR-16 as internal control }\end{array}$ & $0.4078 \pm 1.3922$ & & \\
& & & -2.0512 & \\
Healthy control & miR-21 as target & $2.4590 \pm 1.6084$ & \\
& miR-16 as internal control & & \\
\hline
\end{tabular}

cer and healthy controls. The results showed that miR-21 had a significant upregulation in ovarian cancer patients (Table 1). MiR-21 expression in the ovarian cancer samples was upgraded four times when compared with the control $(p<0.05)$. The mean $\pm \mathrm{SD} \Delta \mathrm{Cq}$ value of miR21 was $0.4078 \pm 1.3922$ in the 37 ovarian cancer samples, and $2.4590 \pm 1.6084$ in the healthy control subjects.

\subsection{Plasma miR-21 is associated with cancerous ma- lignancy rates in the FIGO stage}

To determine the important role of plasma miR-21 in the development and progression of ovarian cancer, we examined the association of miR-21 expression at various stages of malignancy in ovarian cancer (Table 2). Classification of cancer based on FIGO stage, i.e. early-stage ovarian cancer patients (numbering 19 in total) had a mean \pm SD $0.9421 \pm 1.0198$, and advanced-stage ovarian cancer patients (18 in total) had a mean \pm SD $-0.1561 \pm 1.5321$. Based on the results obtained, miR-21 in advanced-stage ovarian cancer patients experienced a two-fold upregulation compared with early-stage cancer patients $(p<0.05$, ANOVA). Meanwhile, miR-21 in early-stage ovarian cancer of plasma undergoes upregulation three $t p<0.05$ ). The highest increase of expression was found in miR-21 plasma of advanced ovarian cancer when compared with healthy control that was 6 times $(p<0.05)$. These results expand on the current knowledge in cancer research, showing that the expression of miR-21 in plasma will have upregulation in accordance with the stage of the malignancy. There is not only an increase at the advanced stage, but in the early stage, as well, with plasma miR-21 increasing three-fold, which suggests that miR-21 can be a promising biomarker candidate for the early detection of ovarian cancer.

\section{Discussion}

Ovarian cancer is one of the most severe forms of cancer that can cause death and occur only in women. In its early stages, ovarian cancer does not show specific symptoms that might encourage patients to undergo an early examination. In addition, the location of the ovary organs in the abdominal cavity means that an examination cannot be done consciously like with breast cancer.

Weak examination using CA 125 biomarkers also causes a false positive ovarian cancer diagnosis. CA 125 is very weak for specificity (SP) and sensitivity (SN), so it is not a reliable biomarker in screening in early detection of ovarian cancer (U.S. Preventive Services Task Force 2004; Coticchia et al. 2008; Rauh-Hain et al. 2011). CA125 values in normal serum range from $0-35 \mathrm{U} / \mathrm{mL}$, with an excess of these values indicating a malignancy or noncancerous disease (Bhatt et al. 2010). Based on observations on patient status in the Medical Record Room of Dr. Sardjito General Hospital from September 2015 to April 2016, the obtained data revealed that of 52 patients measured for the number of CA-125, eight patients that had CA-125 levels $<35 \mathrm{U} / \mathrm{mL}$ were diagnosed with a tumor, 19 patients that had CA-125 levels $>35 \mathrm{U} / \mathrm{mL}$ were diagnosed with a tumor, and 25 patients with CA-125 levels $>35 \mathrm{U} / \mathrm{mL}$ were diagnosed with ovarian cancer (based on definitive PA results).

TABLE 2 Expression of miR-21 in plasma samples of early and advanced ovarian cancer compared with the healthy controls.

\begin{tabular}{|c|c|c|c|c|c|}
\hline Plasma samples & miRNA targeted & $\operatorname{Mean}(\Delta \mathrm{Cq}) \pm \mathrm{SD}$ & Remarks & $\Delta \Delta \mathrm{Cq}$ & Fold change $\left(2^{-\Delta \Delta C q}\right)$ \\
\hline $\begin{array}{l}\text { Early-stage } \\
\text { ovarian cancer }\end{array}$ & $\begin{array}{l}\text { miR-21 as target } \\
\text { miR-16 as internal control }\end{array}$ & $0.9421 \pm 1.0198$ & $\begin{array}{l}\text { Advanced-stage ovarian } \\
\text { cancer compared with } \\
\text { early-stage }\end{array}$ & -1.0982 & 2.1410 \\
\hline $\begin{array}{l}\text { Advanced- } \\
\text { stage ovarian } \\
\text { cancer }\end{array}$ & $\begin{array}{l}\text { miR-21 as target } \\
\text { miR-16 as internal control }\end{array}$ & $-0.1561 \pm 1.5321$ & $\begin{array}{l}\text { Advanced-stage ovarian } \\
\text { cancer compared with } \\
\text { healthy control }\end{array}$ & -2.6151 & 6.1269 \\
\hline Healthy control & $\begin{array}{l}\text { miR-21 as target } \\
\text { miR-16 as internal control }\end{array}$ & $2.4590 \pm 1.6084$ & $\begin{array}{l}\text { Early-stage ovarian cancer } \\
\text { compared with healthy } \\
\text { control }\end{array}$ & -1.5169 & 2.8618 \\
\hline
\end{tabular}


Research related to miRNA has been widely performed for the purpose of diagnosis and prognosis physiopathologie malignancy. Multiple profiling has indicated that microRNA expression significantly changes in the development of ovarian cancer (Iorio et al. 2007; Nam et al. 2008). The microRNA marker in circulating tumor exosomes in ovarian cancer patients demonstrates a high level of correlation with the expression of microRNA in the primary tumor (Taylor and Gercel-Taylor 2008).

MicroRNA is contained in small particles and these particles can protect against microRNA from RNase activity (Mo et al. 2012). MicroRNA plays an important role in cellular differentiation, cancer development, angiogenesis, immune response, cell growth, stress response, and cell death, via modulation of the target mRNA transcription expression (Kuehbacher et al. 2008; Davidson-Moncada et al. 2010; Song et al. 2010; Liu et al. 2011; Koutsaki et al. 2014).

Research has been widely conducted on the expression of miR-21 in ovarian cancer, whether on ovarian tissue, serum, or plasma. One study using a malignant and normal ovarian tissue sample reported an overexpression of miR21 in ovarian cancer compared with normal tissue (Iorio et al. 2007). Taylor and Gercel-Taylor (2008) studies using serum samples in serous adenocarcinoma patients, and controls using benign ovaries, the results showed several upregulations of miR-21, -141, -200a, -200c, -203, -20, and -214 in ovarian cancer. Xu et al. (2013) also showed that patients with EOC had significantly increased serum miR-21 compared with healthy controls, and serum expression of miR-21 had a correlation with FIGO stage.

The recent used both ovarian cancer plasma and healthy controls aimed at developing a minimally invasive biomarker. The results showed that plasma miR-21 in ovarian cancer had upregulated four times compared with the healthy control ( $\mathrm{p}<0.05$, Mann-Whitney test). Based on the FIGO stage, the expression of miR-21 increased along with the increase in stages. The expression of miR-21 in early-stage ovarian cancer was upregulated when compared with the healthy controls $(\mathrm{p}<0.05$, ANOVA). An increased expression of miR-21 also occurred in advanced ovarian cancer compared with the early stage. Based on these results, miR-21 can be used as a diagnostic biomarker candidate of ovarian cancer as it was found to undergo significant expression changes in the early stages of ovarian cancer.

\section{Conclusions}

This study revealed that the level of miR-21 in the plasma of patients with ovarian cancer showed an increase, and can be associated with FIGO stage. Increased miR-21 expression in malignancy conditions can aid in cancer research, especially in the development of diagnostic and prognostic biomarkers, and may be targeted for a personalized medicine ovarian cancer treatment.

\section{Acknowledgments}

We would like to thank to Obstetrics/Gynecology resident doctors, Dr. Sardjito General Hospital Bougenville 1 and 2 of 2015-2016 who helped take the blood of presurgical patients, and the team of GenomiR Faculty Medicine UGM for always motivating us for conducting microRNA research in Indonesia. We would like to thank Mrs. Nanik Nermawati and Mrs. Fatma who always provide support and help for difficulties doing microRNA research. Thanks to all staff of molecular biology laboratory of Radio Putro, FM UGM who has helped this research.

\section{Authors' contributions}

The first author, AIK conducted a collection of presurgical patient plasma samples, carried out the laboratory work such as RNA isolation, cDNA synthesis, qRT-PCR, analyzed the data and wrote the manuscript, SNC and ASF assisted in collecting plasma samples of patients with ovarian cancer, informed consent patient, and looking for secondary data in medical record, DST wrote the manuscript. AT, HP, TA, SMH designed the study, providing guidance in ovarian cancer research and microRNA.

\section{Competing interests}

The research was funded by the GenomiR Faculty of Medicine UGM and Risbin Iptekdok, the Ministry of Health 2015.

\section{References}

Bast RC, Hennessy B, Mills GB. 2009. The biology of ovarian cancer: new opportunities for translation. Nat Rev Cancer 9(6):415-428. doi:10.1038/nrc2644.

Bhatt AN, Mathur R, Farooque A, Verma A, Dwarakanath BS. 2010. Cancer biomarkers - current perspectives. Indian J Med Res. 132:129-149.

Cannistra SA. 2004. Cancer of the ovary. N Engl J Med. 351(24):2519-2529. doi:10.1056/NEJMra041842.

Chao A, Lai CH, Chen HC, Lin CY, Tsai CL, Tang $\mathrm{YH}$, Huang HJ, Lin CT, Chen MY, Huang KG, Chou HH, Chang TC, Chen SJ, Wang TH. 2014. Serum microRNAs in clear cell carcinoma of the ovary. Taiwan J Obstet Gynecol. 53(4):536-541. doi:10.1016/j.tjog.2014.07.005.

Chen Y, Zhang L, Hao Q. 2013. Candidate microRNA biomarkers in human epithelial ovarian cancer: systematic review profiling studies and experimental validation. Cancer Cell Int. 13(1):86. doi:10.1186/14752867-13-86.

Cho KR, Shih IM. $2009 . \quad$ Ovarian cancer. Annu Rev Pathol: Mech Dis. 4(1):287-313. doi:10.1146/annurev.pathol.4.110807.092246.

Coticchia CM, Yang J, Moses MA. 2008. Ovarian cancer biomarkers: Current options and future 
promise. J Natl Compr Canc Netw. 6(8):795-802. doi:10.6004/jnccn.2008.0059.

Davidson-Moncada J, Papavasiliou FN, Tam W. 2010. MicroRNAs of the immune system: roles in inflammation and cancer. Ann N Y Acad Sci. 1183(1):183-194. doi:10.1111/j.1749-6632.2009.05121.x.

Iorio MV, Visone R, Di Leva G, Donati V, Petrocca F, Casalini P, Taccioli C, Volinia S, Liu CG, Alder H, Calin GA, Ménard S, Croce CM. 2007. MicroRNA signatures in human ovarian cancer. Cancer Res. 67(18):8699-8707. doi:10.1158/0008-5472.CAN-071936.

Koutsaki M, Spandidos DA, Zaravinos A. 2014. Epithelial-mesenchymal transition-associated miRNAs in ovarian carcinoma, with highlight on the miR-200 family: Prognostic value and prospective role in ovarian cancer therapeutics. Cancer Lett. 351(2):173-181. doi:10.1016/j.canlet.2014.05.022.

Kuehbacher A, Urbich C, Dimmeler S. 2008. Targeting microRNA expression to regulate angiogenesis. Trends Pharmacol Sci. 29(1):12-15. doi:10.1016/j.tips.2007.10.014.

Liu ZY, Zhang GL, Wang MM, Xiong YN, Cui HQ. 2011. MicroRNA-663 targets TGFB1 and regulates lung cancer proliferation. Asian Pac J Cancer Prev. 12(11):2819-2823.

Mezzanzanica D, Bagnoli M, De Cecco L, Valeri B, Canevari S. 2010. Role of microRNAs in ovarian cancer pathogenesis and potential clinical implications. Int J Biochem Cell Biol. 42(8):1262-1272. doi:10.1016/j.biocel.2009.12.017.

Mo MH, Chen L, Fu Y, Wang W, Fu SW. 2012. Cell-free Circulating miRNA Biomarkers in Cancer. J Cancer 3:432-448. doi:10.7150/jca.4919.

Nam EJ, Yoon H, Kim SW, Kim H, Kim YT, Kim JH, Kim JW, Kim S. 2008. MicroRNA expression profiles in serous ovarian carcinoma. Clin Cancer Res. 14(9):2690-2695. doi:10.1158/1078-0432.CCR-071731.

Qu H, Xu W, Huang Y, Yang S. 2011. Circulating miRNAs: promising biomarkers of human cancer. Asian Pac J Cancer Prev. 12(5):1117-1125.

Rauh-Hain JA, Krivak TC, Del Carmen MG, Olawaiye AB. 2011. Ovarian cancer screening and early detec- tion in the general population. Rev Obstet Gynecol. 4(1):15-21.

Resnick KE, Alder H, Hagan JP, Richardson DL, Croce CM, Cohn DE. 2009. The detection of differentially expressed microRNAs from the serum of ovarian cancer patients using a novel real-time PCR platform. Gynecol Oncol. 112(1):55-59. doi:10.1016/j.ygyno.2008.08.036.

Song T, Xia W, Shao N, Zhang X, Wang C, Wu Y, Dong J, Cai W, Li H. 2010. Differential miRNA expression profiles in bladder urothelial carcinomas. Asian Pac J Cancer Prev. 11(4):905-911.

Suryawanshi S, Vlad AM, Lin HM, Mantia-Smaldone G, Laskey R, Lee M, Lin Y, Donnellan N, KleinPatel M, Lee T, Mansuria S, Elishaev E, Budiu R, Edwards RP, Huang X. 2013. Plasma MicroRNAs as novel biomarkers for endometriosis and endometriosis-associated ovarian cancer. Clin Cancer Res. 19(5):1213-1224. doi:10.1158/1078-0432.CCR12-2726.

Taylor DD, Gercel-Taylor C. 2008. MicroRNA signatures of tumor-derived exosomes as diagnostic biomarkers of ovarian cancer. Gynecol Oncol. 110(1):13-21. doi:10.1016/j.ygyno.2008.04.033.

US Preventive Services Task Force. 2004. Screening for ovarian cancer: recommendation statement. Ann Fam Med. 2(3):260-262. doi:10.1370/afm.200.

Xu YZ, Xi QH, Ge WL, Zhang XQ. 2013. Identification of serum microRNA-21 as a biomarker for early detection and prognosis in human epithelial ovarian cancer. Asian Pac J Cancer Prev. 14(2):1057-1060. doi:10.7314/apjcp.2013.14.2.1057.

Yang H, Kong W, He L, Zhao JJ, O’Donnell JD, Wang J, Wenham RM, Coppola D, Kruk PA, Nicosia SV, Cheng JQ. 2008. MicroRNA expression profiling in human ovarian cancer: miR-214 induces cell survival and cisplatin resistance by targeting PTEN. Cancer Res. 68(2):425-433. doi:10.1158/0008-5472.CAN07-2488.

Zhou L, Zhao YP, Liu WJ, Dong J, Chen WY, Zhang TP, Chen G, Shu H. 2012. Circulating microRNAs in cancer: diagnostic and prognostic significance. Expert Rev Anticancer Ther. 12(2):283-288. doi:10.1586/era.11.197. 